\title{
REFLEKSYJNOŚĆ W ŚWIETLE TEKSTÓW EUROPEJSKIEGO SYSTEMU OPISU KSZTAECENIA JĘZYKOWEGO
}

\author{
Reflexivity in the light of the Common European Framework \\ of Reference for Languages
}

The Common European Framework of Reference for Languages is a document characterized by a high level of generality, addressed to a wide range of readers. The conceptual paradigm included in the document could constitute the basis for a new trend in language didactics; however, a lot of further work and research should be carried out for the new approach to achieve the status of independent and efficient methodology. The first prerequisite for introducing necessary modifications is a reflexive approach to the recommendations of CEFR, especially those which are methodological in character. The lack of any rules or procedures showing how to facilitate the achievement of learning objectives is the most frequent objection made against the CEFR. The focus on what has to be taught should go along with how to teach and why. Reflexivity which occupies a marginal position in the CEFR has to become a priority for its users if the methodology outlined there is to constitute the new era in language didactics.

Keywords: reflexivity, Common European Framework of Reference for Languages (CEFR), action-oriented approach, general competences, communicative language competences, strategies, language activities, tasks

Słowa kluczowe: refleksyjność, Europejski system opisu kształcenia językowego (ESOKJ), podejście ukierunkowane na działanie, kompetencje ogólne, językowe kompetencje komunikacyjne, strategie, działania językowe, zadania 


\section{Wprowadzenie}

Problem refleksyjności znalazł się w ostatnich latach w centrum uwagi glottodydaktyków. Mówi się o refleksyjności w kształceniu i doskonaleniu nauczycieli, o podejściu refleksyjnym do nauczania i uczenia się języków obcych, o refleksji w praktycznym użyciu języka, o refleksyjnych postawach uczniów i nauczycieli itp. Wymienione kwestie, do których proponuje się podejście refleksyjne stanowią trzon procesu nauczania/uczenia się języka. Zagadnienia te podejmowane są również w opublikowanym przez Radę Europy Europejskim systemie opisu kształcenia językowego ${ }^{1}$. Minęło już 12 lat od publikacji tego dokumentu i z całą stanowczością należy stwierdzić, że wdrażanie jego zaleceń powinno być refleksyjne.

Okres przygotowywania ESOKJ, jego opublikowania i rozpowszechniania, a następnie wdrażania do praktyki postulatów Rady Europy przyczynił się do zwrotu w kierunku refleksyjności w glottodydaktyce w szerokim słowa tego znaczeniu. Chronologicznie rzecz ujmując, refleksyjność jest podstawą i równocześnie wymogiem Europejskiego systemu. Dokument powstał w wyniku refleksji i analiz ekspertów Rady Europy którzy, dostrzegając słabości metodologii komunikacyjnej, podjęli próbę udoskonalenia systemu kształcenia językowego i dostosowania go do nowych potrzeb jednoczącej się Europy. Jest on owocem naukowej refleksji prowadzonej przez dziesięć lat, refleksji systematycznie podtrzymywanej chęcią uzyskania przejrzystości i koherencji językowej, zagubionej w olbrzymiej różnorodności systemów ewaluacji i certyfikacji w Europie (Rosen, 2006: 11).

ESOKJ, który sam w sobie jest dziełem refleksji ekspertów Rady Europy, po upowszechnieniu wymaga od swoich użytkowników refleksyjnego odbioru zamieszczonych w nim treści. Jednym z celów Europejskiego systemu opisu jest pobudzenie do refleksji osób odpowiedzialnych za kształcenie językowe oraz nauczycieli praktyków. Posługując się tą samą terminologią, nauczyciele różnych języków i kultur, pochodzący z różnych krajów, mogą się porozumieć i porównywać swoje decyzje pedagogiczne. Ten wspólny język nauczycieli i osób odpowiedzialnych za ich przygotowanie zawodowe ułatwia wzajemne zrozumienie i wzbogacenie doświadczeń.

W niniejszym artykule rozważymy pokrótce, czym jest refleksyjność i postaramy się odpowiedzieć na pytanie, dlaczego teksty ESOKJ wymagają refleksyjnego odbioru, szczegółowej analizy, krytycznego czytania, zdystan-

\footnotetext{
${ }^{1}$ Rada Europy. 2003. Europejski system opisu kształcenia językowego: uczenie się, nauczanie, ocenianie. Warszawa: Wydawnictwa CODN; używane skróty w artykule to: ESOKJ, Europejski system opisu, Europejski system, System opisu.
} 
sowania się wobec proponowanych rozwiązań. Nie analizujemy szczegółowo całego dokumentu, lecz wskazujemy na kilka problemów, które najczęściej budzą wątpliwości użytkowników i wymagają przemyśleń i refleksyjnego spojrzenia. Mówiąc o potrzebie refleksji w czytaniu tekstów Systemu opisu oraz $w$ realizacji jego postulatów w kształceniu językowym, mamy na uwadze dwie podstawowe kwestie: radzenie sobie z nowościami tu i teraz, wdrażanie do praktyki jego zaleceń oraz wspomaganie procesu zmierzającego do ukonstytuowania się nowej metodologii.

\section{Pojęcie refleksyjności}

Refleksyjność jest pojęciem trudnym do zdefiniowania, a jej definicja zależy bezpośrednio od dziedziny, w zakresie której działa dana jednostka. Z definicji zamieszczonych w literaturze (np. Le Boterf, 2010) wynika, iż refleksyjność jest najczęściej rozumiana jako zdystansowanie się wobec danej rzeczywistości, czy problemów, przyjęcie krytycznej postawy i gotowość do wszechstronnej analizy zagadnień lub sytuacji. Postawa refleksyjna to szukanie kompromisu, doskonalszych rozwiązań, nieakceptowanie faktów i decyzji, zastanej sytuacji itd. bez zastanowienia się nad ich racją bytu, bez rozważenia mocnych i słabych stron własnej lub czyjejś propozycji.

Refleksja nad wykonanymi działaniami, zdolność krytycznego zdystansowania się do swego działania, są traktowane w świecie pracy jako oznaki profesjonalizmu i wysokich kompetencji pracownika. Umiejętność analizowania czerpiemy z umiejętności praktycznych (savoir-faire) i uwarunkowań osobowościowych (savoir-être), które to stale wzbogacają nasze kompetencje i przyczyniają się do ich rozwoju. Stąd też możemy usytuować pojęcie refleksyjności w kontekście kompetencji.

Według G. Le Boterfa (2010: 168), „kompetentny profesjonalista to nie tylko ten, który potrafi kompetentnie działać, ale również ten, który potrafi opisać dlaczego i w jaki sposób działa oraz dlaczego działa w taki, a nie inny sposób, aby działanie stało się skuteczne. Refleksyjność to podstawa w tworzeniu profesjonalizmu". Profesjonalny pracownik umie przekształcić swoje działanie na doświadczenie oraz wyciągać lekcję z doświadczenia. Nie zadawala się samym działaniem lub wykonaniem czegoś. Czyni ze swej praktyki zawodowej sposobność do tworzenia nowej wiedzy i nowych umiejętności. Wychodząc z założenia, iż wymiar refleksyjny leży w samym sercu kompetencji zawodowych oraz jest elementem niezbędnym do ich funkcjonowania i rozwoju, refleksyjność może być pojmowana jako niezależna kompetencja złożona z wiedzy, umiejętności i postaw. Kompetencja, która 
powinna być bezsprzecznie kształtowana u przyszłych i już czynnych zawodowo nauczycieli, chociażby po to, aby potrafili interpretować kluczowe pojęcia z zakresu glottodydaktyki.

\section{Ogólny charakter ESOKJ}

Europejski system opisu to narzędzie ogólne w swej koncepcji i adresowane do szerokiego kręgu odbiorców. Jednym z podstawowych założeń twórców dokumentu był jego uniwersalny charakter. Skoro jest ogólny, przeznaczony do stosowania w różnych kontekstach i systemach edukacyjnych, oznacza to, iż wymaga refleksyjnego i krytycznego podejścia: właściwego zrozumienia i selekcji treści, uzupełnienia luk itd. w perspektywie zastosowania w każdym z obszarów kształcenia językowego.

W podrozdziale 1.6. Systemu opisu twórcy dokumentu informują, że jest on wszechstronny, przejrzysty i spójny, a więc nie może narzucać „jedynych, powszechnie obowiązujących reguł”, lecz powinien „być na tyle otwarty i elastyczny, by w razie potrzeby mógł ulec modyfikacji podyktowanej konkretną sytuacją" (ESOKJ, 2003: 19). Wszechstronny, znaczy również: uniwersalny - czyli możliwy do wykorzystania w planowaniu i organizowaniu kształcenia językowego; elastyczny - dający się zastosować w różnych okolicznościach; otwarty - dopuszczający możliwość dalszego udoskonalania i modyfikacji; dynamiczny - uwzględniający zmiany zaistniałe w systemie kształcenia w trakcie jego użytkowania; przyjazny dla użytkownika - czytelny i zrozumiały; niedogmatyczny - niezwiązany z żadnym konkretnym podejściem teoretycznym (ESOKJ, 2003: 19).

Wnikając w szczegóły powyższej charakterystyki trudno nie zauważyć, iż dokument pozostawia swoim odbiorcom nie tylko szeroki margines swobody, ale równocześnie czyni ich odpowiedzialnymi za prawidłową interpretację i stosowanie jego zaleceń w zależności od potrzeb edukacyjnych i warunków kształcenia. Powtarzająca się formuła ...możliwy do... jest potwierdzeniem jego niedogmatycznego podejścia do nauczania języka: proponuje takie czy inne rozwiązanie, ale go nie narzuca.

$Z$ jednej strony ogólny charakter ESOKJ stanowi niezaprzeczalną wartość dokumentu: to pierwszy w historii dydaktyki system opisu dla wszystkich języków, stąd jego szeroki zasięg i zastosowanie w różnych systemach edukacyjnych. Z drugiej zaś, w tej pozornie urzekającej swobodzie zawiera się ogromna trudność, ryzyko nieprawidłowego odbioru, interpretacji i zastosowania jego dyrektyw. Narzuca się więc wniosek, iż im większy stopień ogólności, tym większy wymóg refleksyjności, krytycznego podejścia do zawartych w nim zaleceń. 


\section{Refleksyjni użytkownicy}

Kontynuując rozważania na temat uniwersalnego i otwartego charakteru rozwiązań zaproponowanych przez Europejski system, warto wskazać na inny aspekt dokumentu, na fragmenty, gdzie autorzy w sposób eksplicytny zwracają się do użytkowników, przenosząc na nich ciężar odpowiedzialności za podejmowane decyzje, apelując niejako o podejście refleksyjne. Twórcy zachęcają uczących się/użytkowników języka do określania celów indywidualnych, do których dążą, na podstawie opisów zawartych w dokumencie. Aby osoby zainteresowane mogły prawidłowo dokonywać wyborów, począwszy od rozdziału 4., po każdej partii nowego materiału umieszczono w Systemie opisu zestawy pytań w szarych tabelkach. Pozwalają one zorientować się „w jakim stopniu ta część odnosi się do potrzeb i zagadnień nurtujących danego czytelnika" (ESOKJ, 2003: 8). Jeżeli dana część materiału nie jest dla niego istotna, tzn. nie odnosi się do sytuacji, w której się znalazł, może ją pominąć. Autorzy podkreślają, „że ani zestaw kategorii opisu, ani ich przykładowe rozwinięcia nie stanowią zamkniętej, skończonej całości [...]. Podawane przez nas przykłady są tylko pewną sugestią. Można je przyjąć lub odrzucić, można uzupełnić własnymi. Czytelnik ma tu wszelką swobodę, gdyż to on wie najlepiej, jakie są jego cele i o jaki produkt mu chodzi" (ESOKJ, 2003: 8-9).

W całym dokumencie znajdują się aż 62 szare ramki, a w nich uwagi typu: „Użytkownicy Europejskiego systemu opisu kształcenia językowego mogą rozważyć i - jeśli uznają za stosowne - określić...". Dla przykładu, na stronie 59. twórcy dokumentu apelują do osób (użytkowników) podejmujących decyzje odnośnie treści nauczania (do autorów programów i podręczników, do nauczycieli), którzy, po zbadaniu potrzeb uczących się, zaplanują serie zadań różnego typu, w zakresie czterech wymienionych sfer życia i przygotują uczących się do ich wykonania.

Użytkownicy Europejskiego systemu opisu kształcenia językowego mogą rozważyć i - jeśli uznają za stosowne - określić:

- zadania komunikacyjne w sferze prywatnej, publicznej, zawodowej i/lub edukacyjnej, które uczący się będą wykonywać / do których wykonywania powinni zostać przygotowani / które powinni umieć wykonywać;

- $\quad$ sposób oceny potrzeb uczących się, na podstawie których dokonuje się wyboru zadań.

(ESOKJ, 2003: 59)

Krytyczna analiza potrzeb staje się kluczem, według którego dobiera się treści nauczania i proponuje odpowiednie typy zadań w poszczególnych sferach życia. Brak recept i gotowych rozwiązań to dla użytkowników trudna 
droga selekcji materiałów i doboru tematów odpowiadających konkretnej grupie uczących się. Nie może być jednak inaczej, skoro dokument nie dotyczy żadnego konkretnego języka, lecz jest systemem opisu wszystkich języków. Taką koncepcję przyjęli jego twórcy, taka jest jego filozofia.

\section{Nowy paradygmat pojęciowy}

Europejski system opisu można traktować jako kontynuację podejścia komunikacyjnego lub jako zapowiedź nowego kierunku w dydaktyce językowej: podejścia ukierunkowanego na działanie (zob. Janowska, 2011). Jednak, aby tak się stało musi on zostać poddany szczegółowej analizie, która pozwoli wyeliminować wszelkie wahania, niepewności, nieścisłości. Mimo przekonania o rodzącej się nowej metodologii, J.-J. Richer stwierdza, że dotychczas „nie weszliśmy jeszcze w nową erę metodologiczną, tzn. w „perspektywę działaniową", następującą po podejściu komunikacyjnym, ale znajdujemy się w okresie wahań, niepewności i niejasności, który poprzedza ewentualne pojawienie się nowej konfiguracji metodologicznej" (2012: 5). Zwłaszcza na planie metodologicznym pozostajemy $w$ zawieszeniu pomiędzy nowym typem podejścia komunikacyjnego o wyraźnych tendencjach eklektycznych a kształtowaniem się perspektywy ukierunkowanej na działanie, która pozostaje wciąż na etapie programowym. Europejski system opisu zawiera zespół pojęć, który może z powodzeniem stanowić podstawę nowej metodologii. Niezbędne są jednak badania wyjaśniające i prostujące niedoskonałości ESOKJ, aby nowe podejście ukierunkowane na działanie mogło się w pełni ukonstytuować i by nie pozostawało tylko etykietką służącą do promowania nowych podręczników do nauki języka (Richer, 2012: 5). Główne zarzuty pod adresem systemu opisu to: nieprecyzyjność $w$ definiowaniu wielu podstawowych pojęć, takich jak np. kompetencja, zadanie, strategie czy traktowanie rodzącej się perspektywy jako zwykłej kontynuacji podejścia komunikacyjnego.

\section{Kompetencja - brak konsensusu}

Wiele dyskusji toczy się wokół pojęcia kompetencji, a autorzy opracowań (Beacco, 2007; Castellotti, 2002; Perrnoud, 2011) i uczestnicy debat stwierdzają jednogłośnie brak jasnej i powszechnie przyjętej definicji kompetencji. Pojęcie to jest postrzegane jako niestabilne, niewyraźne, polisemiczne; widoczny jest brak konsensusu odnośnie jego znaczenia. Jest ono często używane na wszystkich poziomach refleksji na temat nauczania i uczenia się języków, mimo iż nigdy nie zostało w sposób jednoznaczny zdefiniowane. 
Perrenoud (2011: 11) słusznie zauważa, iż jak długo pojęcie kompetencji będzie nieprecyzyjne, labilne, zdefiniowane przez każdego z dydaktyków na własny sposób, tak długo nie będzie wiadomo, czy szkoła rozwija kompetencje. Nic też dziwnego, iż dydaktycy (np. Bronckart i Buela, 2005) postulują pilną potrzebę wyjaśnienia statusu pojęcia kompetencji.

Pojęcie "kompetencji” zajmuje centralną pozycję w ESOKJ i pomimo tego, że pojawia się tu (w różnych formach) 343 razy, nie zostało precyzyjnie zdefiniowane: „Posługiwanie się językiem, w tym także uczenie się języka, obejmuje działania podejmowane przez uczestników życia społecznego, którzy - jako osoby indywidualne - posiadają i stale rozwijają swoje kompetencje zarówno ogólne, jak i językowe kompetencje komunikacyjne" (ESOKJ, 2003: 20). Językowa kompetencja komunikacyjna to kompetencja lingwistyczna, socjolingwistyczna i pragmatyczna. Na kompetencje ogólne użytkownika/uczącego się składają się: wiedza, umiejętności, uwarunkowania osobowościowe oraz umiejętność uczenia się.

I właśnie pojęcie kompetencji ogólnych budzi największe kontrowersje. Grupując wewnątrz tej samej kategorii, określanej jako „kompetencje ogólne użytkownika", różne rodzaje podkategorii, na których opiera się kompetencja komunikacyjna, ESOKJ umieszcza posługiwanie się językiem w szerszym kontekście niż to czyniło podejście komunikacyjne, co zmusza nauczycieli do zajmowania się nie tylko wymiarem językowym i socjokulturowym, ale do włączenia w swoją praktykę pedagogiczną tych parametrów kognitywnych, proceduralnych, psychologicznych i praktycznych (wynikających z doświadczenia), które odgrywają ważną rolę w akwizycji języka obcego (Richer, 2012: 54). Problem jednak w tym, w jaki sposób należy to robić w codziennej praktyce pedagogicznej.

Za problematyczne można również uznać składowe kompetencji ogólnych i ich rozumienie. Wystarczy wspomnieć kompetencję nazywaną savoir-être (uwarunkowania osobowościowe), które jest pojęciem bardzo nieprecyzyjnym. Trudno odgadnąć, na czym opierają się kompetencje wchodzące w skład savoirêtre, na podstawie czego zostały ukonstytuowane, jaka jest ich racja bytu. Jest to pojęcie mętne, nieprzejrzyste, ponieważ savoir-être, które obejmuje wartości moralne, cechy charakterologiczne, uzdolnienia, cechy osobowości, zainteresowania, zachowania etc., odsyła do różnorodnych dziedzin wiedzy.

Jak już wspomniano, jeśli definicja kompetencji będzie niejasna, jak określić, co nasz uczeń powinien umieć? Tak więc widzimy tu konieczność głębokiej refleksji i analizy tego podstawowego pojęcia używanego w ESOKJ, a budzącego wątpliwości. 


\section{Luki metodologiczne: koncentracja na rezultatach, brak metod osiągania celów}

W powszechnej opinii, ESOKJ to przede wszystkim narzędzie ewaluacji, co odnotowano już w jego podtytule: uczenie się, nauczanie, ocenianie. Jednym z jego zasadniczych celów jest ułatwienie określania stopnia znajomości języka. Funkcję tę spełniają wskaźniki biegłości językowej opracowane dla sześciu poziomów (A1-C2). Drugi aspekt tej funkcji to uznawalność certyfikacji i dyplomów. „Przyjęcie wspólnej podstawy opisu celów, treści i metod kształcenia pozwoli zapewnić przejrzystość oceny kursów, planów i programów nauczania, a także świadectw i dyplomów. [...] Określenie obiektywnych kryteriów opisu poziomów biegłości językowej, ułatwi porównywanie i wzajemne uznawanie kwalifikacji uzyskiwanych w ramach różnych systemów edukacyjnych" (ESOKJ, 2003: 13).

Wskaźniki biegłości językowej to niezaprzeczalnie zasadnicza wartość i główna oś dokumentu. To one zostały zaakceptowane w pierwszej kolejności przez odbiorców i zastosowane w praktyce. Stanowią wspólną płaszczyznę odniesienia $w$ procesie ewaluacji dokonywanej według różnych kryteriów w różnych systemach edukacyjnych. Jednakże, poza pełnym uznaniem ich przydatności, drugi aspekt tego bogatego repertuaru deskryptorów wydaje się mniej korzystny dla dydaktyki językowej. Zbytnia koncentracja na tym, co uczeń powinien umieć na danym poziomie może przyczynić się do ukierunkowania całego procesu nauczania na osiągnięcia i wyniki ze szkodą dla jakości tego procesu. Poziomy biegłości sugerują zmierzanie prosto do celu z pominięciem wielu etapów właściwych przyswajaniu języka. Wyeksponowanie osiągnięć na poszczególnych poziomach łączy się z konstatacją zaniedbań aspektów metodologicznych procesu. Nadmierna koncentracja na wskaźnikach biegłości nie tylko nie ułatwia rozwijania, doskonalenia zabiegów metodycznych, lecz je wręcz hamuje. Deskryptory opracowane dla poszczególnych kompetencji i poziomów są z pewnością bardzo przydatne jako punkty odniesienia, jako słupki graniczne na drodze, którą należy przebyć, ale nie mówią nic na temat przebiegu procesu nauczania, na temat sposobów osiągania zakładanych celów. Podsumowując, w dokumencie nie został dopracowany aspekt metodologiczny; nie mówi się w jaki sposób należy nauczać/uczyć się, by skutecznie pokonywać trudności i piąć się w górę po skali wyznaczonych poziomów biegłości w zakresie podstawowych działań językowych (recepcji, produkcji, interakcji i mediacji).

W kontekście aspektu metodologicznego pojawia się jeszcze jeden problem. Nieobecność wyraźnie nakreślonej metodologii w ESOKJ sprawia, iż 
największe zagrożenie dla dydaktyki językowej stanowi eklektyzm. Teoretycy i praktycy przestrzegają przed destruktywnym oddziaływaniem tej tendencji czy mody, polegającym na braku koherencji w kształceniu językowym. Bezkrytyczny eklektyzm praktykowany w imię rzekomej skuteczności i dostosowania nauczania do potrzeb uczących się, uwzględnienia ich zainteresowań i priorytetów, stanowi duże zagrożenie dla dydaktyki językowej. Każda metoda, w tym również eklektyczna, musi być spójna i dostosowana do celów, które stawiają sobie jej autorzy. Z punktu widzenia nauczyciela, wypracowanie właściwej postawy i umiejętności niezbędnych do praktykowania w klasie eklektyzmu jest skomplikowanym i długotrwałym procesem, opartym na wiedzy i doświadczeniu pedagogicznym. Jedynie wnikliwa analiza i refleksja użytkowników dokumentu stanowić będą barierę bezpieczeństwa, pozwalającą na pełne wykorzystanie zasobów proponowanych przez ESOKJ bez ryzyka popadania w niebezpieczne skrajności.

\section{O strategiach nauczania i uczenia się}

ESOKJ promuje nauczanie oparte na realizacji zadań ukierunkowanych na rozwiązywanie problemów społecznych w przyszłej pracy zawodowej w krajach posługujących się danym językiem. Działania uczenia się przygotowują uczniów do radzenia sobie w różnych sytuacjach życia codziennego. Realizacja zadań, zarówno tych o charakterze językowym, jak i zadań autentycznych, wymaga użycia strategii. Pojęcie strategii zajmuje ważną pozycję w dokumencie w perspektywie uczenia się przez całe życie. Strategie traktowane są nie jako składowa kompetencji komunikacyjnej, lecz jako odrębna właściwość, połączona tym razem z działaniami językowymi. Rozwijanie kompetencji strategicznej to kolejny obszar, który bez dużej dozy refleksyjności nie znajdzie właściwego zastosowania w procesie kształcenia językowego. Jakie strategie stosować i dlaczego? W jaki sposób ich nauczać realizując program? Te i podobne kwestie wymagają głębokiej refleksji i indywidualnego podejścia do ucznia.

Językowa kompetencja komunikacyjna przejawia się w działaniach językowych produkcji, recepcji, interakcji i mediacji. „Działanie językowe to zastosowanie językowych kompetencji komunikacyjnych w konkretnej sferze życia do stworzenia bądź zrozumienia jednego lub więcej tekstów w celu wykonania danego zadania" (ESOKJ, 2003: 20). To uaktywnienie się kompetencji w działaniach językowych odbywa się poprzez mobilizację strategii, już nie w ich funkcji kompensacyjnej, jak to miało miejsce w modelu M. Canale i M. Swain (1983). W dokumencie sformułowano to w następujący sposób: „Strategie to środki wykorzystywane przez użytkownika języka w celu mobi- 
lizacji i kontroli własnych zasobów językowych oraz uaktywnienia własnych umiejętności i sposobów działania, by w najpełniejszy lub najbardziej ekonomiczny sposób, zgodnie z założonym celem i danym kontekstem komunikacyjnym, skutecznie wykonać dane zadanie" (ESOKJ, 2003: 61).

Mimo odejścia od traktowania strategii jako składowej kompetencji komunikacyjnej, twórcy Systemu opisu nie nadali jej odrębnego statusu, nie nazwali jej wprost „kompetencją strategiczną”, ale połączyli z działaniami językowymi (4.4.1. Działania i strategie produktywne; 4.4.2. Działania i strategie receptywne; 4.4.3. Działania i strategie interakcyjne, 4.4.4. Działania i strategie mediacyjne). W ESOKJ podzielono strategie komunikacyjne na 4 kategorie: „Korzystanie ze strategii komunikacyjnych można postrzegać jako stosowanie wobec różnych rodzajów działań komunikacyjnych - odbioru, interakcji, produkcji własnej i mediacji - czterech zasad metakognitywnych: planowania, wykonania, oceny oraz korekty" (ESOKJ, 2003: 61).

W opinii J.-J. Richera (2012: 116) takie pogrupowanie jest nieodpowiednie, wręcz niebezpieczne, ponieważ, po pierwsze, może doprowadzić do zredukowania różnorodnych typów strategii tylko do wymienionych tutaj czterech klas; po drugie, strategie zostały przedstawione tak, jak gdyby oddziaływały w sposób linearny, podczas gdy tak naprawdę występują w sposób nieuporządkowany i mają charakter iteratywny.

Pod wpływem ESOKJ zaczęto włączać strategie do podręczników języków obcych, ale tradycyjnie znajdujemy w nich przemieszanie strategii językowych i strategii uczenia się. Autorzy jednak w większości przypadków dają pierwszeństwo strategiom uczenia się, rzadziej przywołują strategie kognitywne, natomiast prawie zupełnie pomijają temat strategii metakognitywnych działania językowego $w$ fazie realizacji zadań. A to wydaje się niestosowne, dlatego że, po pierwsze, zadanie zajmuje centralne miejsce w podejściu ukierunkowanym na działanie, po drugie, zadanie charakteryzuje się tym, że może być wykonane przy zastosowaniu różnych strategii.

\section{Zadania i ich realizacja}

Pojęcie kompetencji w ESOKJ jest nierozerwalnie związane z działaniem przebiegającym w pewnym kontekście (językowym, intelektualnym czy fizycznym), bardziej lub mniej złożonym, bardziej lub mniej kolektywnym. Przywołując definicję użycia języka należy podkreślić, że językowa kompetencja komunikacyjna pozostaje w związku z realizacją zadań, które są działaniami intencjonalnymi, indywidualnymi lub kolektywnymi, wpisanymi w określoną sferę życia, ukierunkowanymi na realizację jednego lub więcej 
celów i zakończone dostrzegalnym rezultatem; mogą łączyć w sobie język i działanie oraz, w celu realizacji, wymagają uaktywnienia wraz ze strategiami licznych kompetencji (zob. ESOKJ 2003: 20).

Odnowa metodologiczna zaproponowana w ESOKJ powinna opierać się na dostrzeganiu ścisłej więzi między kompetencjami użytkownika języka a zadaniami, a tak nie jest. Propozycja zadań w wymiarze zaproponowanym przez autorów Systemu opisu jest jeszcze wciąż niewystraczająco powszechna we współczesnych materiałach do nauczania/uczenia się języków obcych. „Jeśli nie dostrzega się tej więzi, przechodzi się obok potencjału odnowy metodologicznej zaproponowanej przez ESOKJ, który wysuwa na plan pierwszy zadania" (Richer, 2012: 98).

Jak już wspomniano, praktykowanie refleksji jest siłą napędową procesu nauczania i uczenia się, pozwala ewoluować działaniom praktycznym poprzez wyłączenie odpowiedzi automatycznych, rutynowych. Refleksja to spojrzenie wstecz, odwołanie się do posiadanej wiedzy i umiejętności w celu konstruowania doskonalszych narzędzi, pozwalających zwiększyć skuteczność działań nauczycielskich.

Perspektywa ukierunkowana na działanie zaproponowana w Europejskim systemie opisu narzuca konieczność przeorientowania roli nauczyciela zdefiniowanej w podejściu komunikacyjnym. Nauczyciel refleksyjny w świetle tekstów ESOKJ doskonale rozpoznaje swój teren pracy, potrafi właściwie interpretować wytyczne dokumentu promującego współczesne tendencje w nauczaniu języków i kultur. Refleksyjność nie ogranicza się do analizy własnego działania po to, aby móc je uczynić bardziej efektywnym, aby wyprowadzić je poza ograniczenia rutyny. Wychodząc poza prostą akumulację, nakładanie się doświadczeń, refleksyjność ułatwia tworzenie świadomości i tożsamości zawodowej.

Reasumując, ESOKJ wymaga nauczyciela kompetentnego, zdolnego do przekazywania wiedzy i wyrabiania umiejętności w kontekstach, wyposażonego w savoir-faire i savoir-être oraz refleksyjność i etykę. Nadszedł czas na nauczyciela fachowca, który potrafi zmobilizować całokształt zasobów, którymi dysponuje jego osobowość w celu rozwiązania problemu lub stawienia czoła trudnościom.

\section{BIBLIOGRAFIA}

Beacco, J.-C. 2007. L'approche par compétences dans l'enseignement des langues: enseigner à partir du Cadre européen de référence pour les langues. Paris: Didier.

Bronckart, J.-P., Bulea, E. 2005. „Coda: pour une approche dynamique des compétences (langagières)" (w:) Repenser l'enseignement des langues: comment identifier et exploiter les compétences (red. J.-P. Bronckart, E. Bulea, M. Pouliot). Lille: Presses Universitaires du Septentrion: 193-222. 
Castellotti, V. 2002. „Qui a peur de la notion de compétence?” (w:) La notion de compétence en langue - Notions en questions 6 (red. V. Castellotti, B. Py). Lyon: E. N. S. Editions: 9-16.

Janowska, I. 2011. Podejście zadaniowe do nauczania i ucznia się języków obcych. Na przykładzie języka polskiego jako obcego. Kraków: Universitas.

Le Boterf, G. 2010. Construire les compétences individuelles et collectives. Paris: Groupe Eyrolles.

Perrenoud, Ph. 2011. Quand l'école prétend préparer à la vie... - Développer des compétences ou enseigner d'autres savoirs. Paris: ESF Editeur.

Rada Europy. 2003. Europejski system opisu kształcenia językowego: uczenie się, nauczanie, ocenianie. Warszawa: Wydawnictwa CODN.

Richer, J.-J. 2012. La didactique des langues interrogée par les compétences. Fernelmont: E. M. E. \& InterCommunications.

Rosen, E. 2006. Le point sur le Cadre européen commun de référence pour les langues. Paris: CLE International. 